\title{
Ishak Score 0
}

National Cancer Institute

\section{Source}

National Cancer Institute. Ishak Score O. NCI Thesaurus. Code C95150.

No evidence of fibrosis. 